\title{
PERUSAHAAN DALAM PERSPEKTIF ISLAM
}

\author{
Muhammad Djakfar \\ Fakultas Ekonomi Jurusan Manajemen Universitas Islam Negeri (UIN) \\ MALIKI Malang, \\ Jln. Gajayana 50 Malang \\ e-mail: dj4kf4r.2010@gmail.com; \\ HP. 08155524601
}

\begin{abstract}
To live, human beings need to work or have a job, and indeed the kind of work they do depends on their preference based on individuals' capabilities and skills. Amongst the most sought professions is having a business activity that needs to be properly managed, and bulding a company becomes one of many ways to make these activities run in a proper way. Bay having a company ones will understand their right and obligations according to practiced rules. It is the author's interest to point out that in the present time where shari'ah-based business activities has started to grow many still have little understanding about a company from an Islamic point of view. For a Muslim businessman, as well as Indonesian citizens, should understand the system of enterprise not only in term of national regulation perspective but also in Islamic point of view. For this purpose, this article makes an effort to integrate the discourse about enterprise in Islamic perspective and in national regulation perspective.
\end{abstract}

Key word : Perusahaan, Hukum Islam (Shari'ah), Regulasi Nasional

Masalah bisnis merupakan aktivitas kehidupan universal umat manusia. Manusia, dalam tingkat peradaban yang bagaimanapun tidak mungkin lepas dari aktivitas bisis kendati mungkin sistem dan praktiknya saja yang berbeda. Manusia melakukan aktivitas bisnis itu tiada lain untuk mencukupi tuntutan asasi dalam hidup yang tidak mungkin ditunda, seperti sandang, pangan, papan, dan lain sebagainya. Bahkan untuk meningkatkan kualitas hidupnya, manusia tidak hanya mengejar yang pokok semata, namun juga yang sekunder, tersier, dan seterusnya. Hal ini tercermin di dalam era modern seperti sekarang ini yang menuntut kebutuhan, sekaligus kualitas hidup yang semakin tinggi. Manusia dalam era ini belum cukup hanya sekadar memenuhi kebutuhan makan, minum, berpakaian dan bertempat tinggal, tetapi menunut kualitas yang jauh lebih tinggi 
dibanding masa-masa sebelumnya, sebagai cermin harga diri dan status sosial mereka di tengah masyarakat.

Bahkan, manusia modern dewasa ini tuntutan kebutuhan hidupnya lebih dari itu. Fenomena semacam ini bisa dicermati dalam hal kebutuhan alat komunikasi dan transportasi yang kian beragam dan semakin canggih yang mulai digandrungi oleh masyarakat luas. Dalam kaitan perkembangan teknologi informasi seperti sekarang ini kebutuhan alat komunikasi dan transportasi yang cepat dan canggih rasanya tidak lagi sebagai kebutuhan pendukung. Tetapi telah bergeser menjadi sebuah kebutuhan mendasar yang setiap saat harus selalu tersedia. Terjadinya perkembangan kebutuhan yang kian besar di kalangan masyarakat, sudah barang tentu telah mendorong lahirnnya aktivitas bisnis baru yang semakin beragam, yang sebelumnya belum pernah ada.

Aktivitas ekonomi (kerja-bisnis) dalam pengertian luas adalah semua bentuk usaha yang dilakukan manusia, baik dalam materi atau non materi, intelektual atau fisik, maupun hal-hal yang berkaitan dengan masalah keduniawian atau keakhiratan (Al-Khayyath, 1995:13). Al-Qur'an yang menjadi sumber pokok ajaran Islam, di dalamnya banyak membicarakan ayat-ayat tentang akidah dan iman yang diikuti dengan ayat-ayat tentang kerja. ${ }^{1}$ Di sisi lain, ayatayat kerja itu dikaitkan pula dengan masalah hukuman dan pahala, baik di dunia maupun di akhirat. ${ }^{2}$

Betapa mulia kerja itu menurut pandangan Islam, sehingga dalam alQur'an banyak ditemukan ayat tentang kerja. Seluruhnya berjumlah 602 kata (AlKhayyath, 1995:13), dengan berbagai bentuknya. Antara lain, terdapat 22 kata 'amal (bekerja), sebagaimana firman-Nya yang artinya:

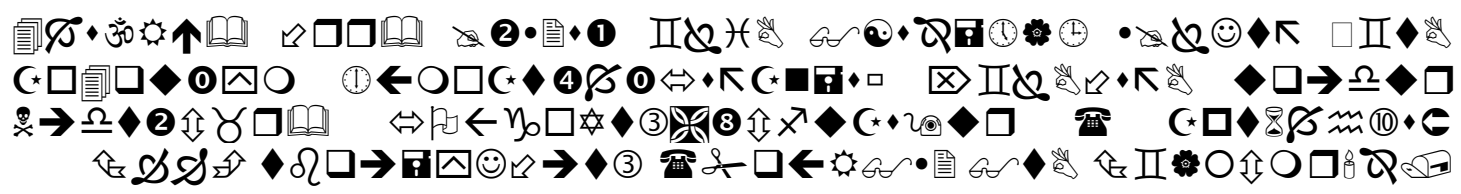

\footnotetext{
${ }^{1}$ Dalam hal ini antara lain lihat surat al-Ikhlas, di mana di dalamnya tertera ayat tentang iman bergandengan dengan amal yang baik.

2 Adanya hukuman dan pahala dalam Islam sesuai dengan ajarannya tentang janji (al-wa'du) dan ancaman (al-waìd) bagi pemeluknya. Maksudnya, barang siapa yang bekerja sesuai dengan ajaran Islam, maka ia akan mendapat pahala dan kebahagiaan di akhirat, sedangkan yang tidak sesuai dengan ajaran Islam akan berdosa dan mendapat siksa kelak di akhirat. Karena itu bagi set iap pebisnis hendaknya memperhatikan dengan sungguh-sungguh hukum Tuhan itu.
} 
“Barang siapa yang mengerjakan amal saleh, baik laki-laki maupun perempuan dalam keadaan beriman, maka sesungguhnya akan Kami berikan kepadanya kehidupan yang baik, dan sesungguhnya akan Kami beri balasan kepada mereka dengan pahala yang lebih baik dari apa yang telah mereka kerjakan." (QS., an-Nahl, 16:97)

Dalam kaitan ini dalam sebuah hadits yang diriwayatkan al-Bukhari ditegaskan, "Tidak ada satu makanan pun yang dimakan seseorang yang lebih baik daripada makanan hasil usahanya sendiri"(Al-Khayyath, 1995:20). Selanjutnya masih dalam kaitan betapa tinggi nilai kerja dalam pandangan Islam, Umar bin Khattab menyatakan "Andaikata aku mati di antara kedua kakiku yang bekerja mencari anugerah Allah swt, adalah lebih kusukai daripada aku mati atau terbunuh sebagai mujahid fi sabilillah" (Al-Khayyath, 1995:21).

Pengertian kerja dalam arti sempit yang bisa didapati pada abad XIX dan awal abad XX-an tidak mencakup pengertian para pengusaha yang berorientasi profit oriented, pegawai, dan para pemilik usaha yang bekerja untuk diri sendiri dan tidak masuk dalam serikat buruh (Al-Khayyath, 1995:24).

Masalahnya karena kerja dalam arti sempit hanya dimaknai setiap potensi yang dikeluarkan manusia untuk memenuhi tuntutan hidupnya yang berupa makanan, pakaian, tempat tinggal dan peningkatan taraf hidupnya. Akan tetapi sebaliknya, pandangan modern tentang gerakan pembaharuan masalah kerja telah mengarah pada usaha-usaha untuk memasukkan mereka ke dalam pengertian yang lebih luas, tidak sebagaimana pemahaman sebelumnya.

Dengan demikian, pengertiannya cenderung mendekati konsep kerja yang ditawarkan Islam dalam bentuk ragam usaha yang melembaga, sebagaimana akan dikemukakan dalam uraian selanjutnya.

\section{RAGAM USAHA: BENTUK-BENTUK PERUSAHAAN}

Dalam literatur (maraji') fikih, atau ekonomi Islam baik yang konvensional (salafiyah/ qadimah) maupun yang modern (khalifiyah/ 'ashriyah) bisa ditemukan beberapa ragam usaha yang telah melembaga di kalangan umat Islam. Kebolehan umat Islam melakukan berbagai bidang usaha secara hukum, antara lain bisa mengacu pada kaidah fikhiyah yang menyatakan "Pada dasarnya, semua bentuk muamalah boleh dilakukan, kecuali ada dalil yang mengharamkannya"(Tim Penulis Dewan Syariah Nasional, 2003:70). Bertolak dari kaidah ini, pada prinsipnya umat Islam diberi kebebasan untuk melakukan usaha dalam berbagai 
bentuknya guna memenuhi kebutuhan hidupnya yang asasi selama hukum tidak melarangnya. Jika sekiranya ada hukum yang melarang karena ada illat (ala san) tertentu sudah barang tentu usaha itu tidak boleh dilakukan oleh siapa pun. Sebuah perusahaan yang usaha pokoknya memproduksi minuman keras (khamr) atau sejenis obat-obatan aditif (narkoba) misalnya, jelas dilarang dalam Islam karena barang yang dihasilkan itu bisa merusak mental dan kesehatan masyarakat. Demikian juga, usaha (bisnis) diskotek, tidak diperkenankan dalam Islam karena dampaknya bagi masyarakat tidak kalah serunya dengan dampak yang ditimbulkan oleh usaha minum-minuman keras dan narkoba. Demikian seterusnya, tentu saja masih banyak contoh lain yang tidak mungkin disebutkan semuanya dalam tulisan ini.

Namun dalam perkembangan dunia modern, beriringan dengan kemajuan ekonomi di berbagai belahan dunia, bagaimanapun Islam harus mampu mengakomodir model lembaga perekonomian kontemporer. Dalam hal ini Islam bisa mengadopsi, memodifikasi, kemudian melegitimasi model lembaga itu untuk kemudian diakui sebagai The Legal Forms of the Islamic Business Enterprise.

Contoh konkret yang bisa ditemukan antara lain lembaga perbankan. Sistem perbankan konvensional maupun modern yang bermula dari Barat ditinjau dari aspek manajemen dan administrasi yang diterapkan kiranya sudah cukup maju dan patut dijadikan rujukan. Namun demikian, di sisi lain menurut kacamata Islam, ada aspek transaksi yang kontra ide dan kontra produksi karena sistem perbankan konvensional mengandung unsur riba. Maka dari itu hal ini perlu dilakukan peninjauan kembali agar rasa kebersamaan dan keadilan bisa dinikmati semua pihak. Karena itu pada akhirnya lahirlah sistem perbankan nonribawi di Indonesia. Di antaranya telah di dikenal apa yang disebut Bank Muamalah Indonesia, dengan beragam produknya yang berdasarkan syariah. Untuk selanjutnya, sejalan dengan tuntutan masyarakat, akhirnya di Indonesia bermunculan perbankan yang berba sis syariah, seperti BNI Syariah, BTN Syariah, Bank Syariah Mandiri, dan masih banyak lagi.

Masih banyak contoh lain, selain bentuk usaha perbankan, seperti asuransi dengan segala macamnya yang juga berbasis syariah. Sebelum ini di kalangan ulama dan para cendekiawan Muslim di seluruh dunia, masalah asuransi ini masih banyak menimbulkan kontroversi (polemik) atau saling tarikmenarik tentang status hukumnya. Akar masalahnya adalah karena dalam sistem 
asuransi konvensional yang lahir di Barat itu menyimpan unsur juhala (ketidakpastian), gharar (risiko), maisir (judi), dan riba (bunga)(Projodikoro,1996:239). Sebab itu untuk mengantisipasi kebutuhan umat (Islam) ke depan akan asuransi ini, Islam telah mencari jalan keluar (wayout) yang bisa menguntungkan semua pihak sehingga lahirlah asuransi yang berbasis syariah. Di antaranya telah dikenal apa yang disebut dengan Asuransi Takaful. ${ }^{3}$

Dari kedua contoh di atas dapat ditangkap bagaimana kelenturan hukum muamalah(Zuhdi, 1993:4), sekaligus fleksibilitas ruang akomoditas dalam Islam. Dengan karakteristik ekonomi Islam yang demikian, berarti Islam memberi peluang seluas-luasya kepada pemeluknya untuk menggeluti peluang usaha baik di bidang keuangan, jasa, maupun sektor riil (manufaktur).

Pada bagian ini akan dikemukakan beberapa ruang usaha yang telah melembaga dalam eknomi Islam. Namun sebagai pembanding, akan disinggung pula ruang usaha dalam sistem ekonomi modern seperti perseroan (syirkah), sehingga dengan demikian kita akan memahami lebih mendalam bahwa kedua sistem ekonomi dari sumber yang berbeda sama-sama memberi ruang usaha yang memadai kepada masyarakat sesuai pilihannya guna memenuhi kebutuhan asasinya.

Perseroan dalam sistem kapitalistik adalah transaksi yang karena transaksi tersebut dua orang atau lebih masing-masing terikat untuk memberikan saham dalam sebuah projek padat modal, dengan memberikan in vestasi, baik berupa harta ataupun kerja agar bisa mendapatkan pembagian hasil dari projek tersebut, baik berupa keuntungan (dividen) maupun kerugian(An-Nabhani, 1996:168). Perseroan tersebut bisa diklasifikasikan menjadi dua, yaitu perseroan orang dan perseroan modal.

Perseroan orang adalah perseroan yang di dalamnya terdapat unsur manusia yang mempuyai pengaruh dalam perseroan tersebut, termasuk dalam hal pembagian hasil keuntungan. Contohnya adalah perseroan Firma dan perseroan Company Limited by Guarantee. Sedangkan dalam perseroan modal tidak terdapat unsur manusia sama sekali, baik nilai maupun pengaruhnya. Perseroan ini adalah seperti perseroan saham (Corporation) dan perseroan Company Limited by Shares (An-Nabhani, 1996:168).

\footnotetext{
3 Dalam perkembangan terakhir di Indonesia guna memenuhi kebutuhan asuransi di kalangan mas yarakat, khususnya umat Islam, sekarang banyak bermunculan asuransi yang berparadigma s yariah. Bahkan tidak jarang asuransi konvensional yang berubah status (konversi) sebagai asuransi syariah.
} 
Jenis perseroan kapitalis yang lain adalah koperasi. Koperasi adalah bentuk penanaman saham antara sekelompok orang yang melakukan kesepakatan antar sesama mereka, untuk mengadakan kerja sama (perseroan) sesuai dengan kondisi tertentu mereka(An-Nabhani, 1996:187). Koperasi biasanya beranggotakan sejumlah orang (bisa tujuh, atau lebih sedikit, ataupun lebih banyak). Setiap tutup tahun buku koperasi harus dilaporkan secara tertulis melalui RAT oleh pengurus mengenai neraca keuangan dan perhitungan laba rugi. Keuntungan dan kerugian koperasi diterima atau ditanggung oleh para anggota, sesuai dengan anggaran dasar koperasi.

Contoh lain jenis perseroan adalah asuransi. Dalam realitas, asuransi bermacam-macam yaitu asuransi jiwa, barang/harta, asuransi beasiswa, asuransi kecelakaan tubuh, dan lain sebagainya. Asuransi merupakan transaksi antara PT. Asuransi dengan tertanggung, di mana pihak tertanggung (insured) meminta kepada penaggung(PT.Asuransi/Insurer) agar memberikan ganti rugi kepada yang bersangkutan. Baik berupa barang atau berupa harganya, apabila terikat dengan barang atau hak milik. Atau dalam bentuk uang apabila terkait dengan jiwa dan sejenisnya, termasuk bila ada kejadian yang menimpa pihak tertanggung dalam jangka waktu tertentu sesuai dengan kesepakatan dalam transaksi.

Adapun bentuk-bentuk usaha dalam Islam bisa diklasifikasikan ke dalam tiga kelompok, yaitu usaha perorangan (fardiyah), usaha bersama (patnership/ syirkah), dan usaha perdagangan negara.

\section{Usaha Perseorangan (Privat Enterprise/Tijaratun Fardiyah)}

Islam membenarkan adanya hak milik pribadi dengan melalui usaha yang sah (legal). Islam menghargai dan memberikan kompetensi pada pemiliknya untuk mengambil inisiatif dalam mengelola dan mengatur agar usaha yang dibangun bisa berkembang.

Hanya saja kepemilikan pribadi dalam Islam tidak tak terbatas, karena kesemuanya pada hakikatnya adalah milik Allah swt dan merupakan amanahNya kepada manusia. Ini berarti berbeda dengan sistem kapitalistik yang melahirkan jarak antara si kaya dan miskin. Akibat lain, akan terjadi kedaulatan terhadap konsumen, kedlaliman sistem harga dan pengejaran keuntungan (Mannan, 1995:64), dengan memanipulasi alam dan manusia. 
Untuk mengantisipasi kedlaliman itu Islam membuat rambu-rambu agar pemilik perusahaan tidak merusak lingkungan alam dan merugikan manusia, baik secara langsung maupun tidak langsung.

\section{Usaha Bersama (Perseroan/Syirkah)}

Dalam kaitan dengan syirkah ini menurut Mahmud Syaltut merupakan suatu yang baru karena belum dikenal oleh fuqaha zaman dahulu yag membagi syirkah menjadi beragam macam. Beragam syirkah yang dikenal akhir-akhir ini dalam Islam:

a. Syirkah 'abdan, yakni syirkah (kerjasama) antara dua orang atau lebih untuk melakukan suatu usaha/pekerjaan yang hasilnya/upahnya dibagi antara mereka menurut perjanjian, misalnya usaha konveksi, bangunan, dan sebagainya. Abu Hanifah dan Malik membolehkan syirkah ini, sedangkan Syafi' i melarangnya.

b. Syirkah muwafadhah, yakni kerja sama antara dua orang atau lebih untuk melakukan suatu usaha dengan modal uang atau jasa dengan syarat sama modalnya, agamanya, mempunyai wewenang melakukan perbuatan hukum dan masing-masing berhak bertindak atas nama syirkah. Para imam mazhab melarang syirkah muwafadhad ini, kecuali Abu Hanifah yang membolehkannya.

c. Syirkah wujuh, yakni kerja sama antara dua orang atau lebih untuk membeli sesuatu tanpa modal uang, tetapi hanya berdasarkan kepercayaan para pengusaha dengan perjanjian profit sharing (keuntungan dibagi antara mereka sesuai dengan bagian masing-masing). Ulama Hanafi dan Hambali membolehkan syirkah ini, sedangkan ulama Syafi'i dan Maliki melarangnya, karena menurut mereka syirkah hanya boleh dengan uang atau pekerjaan, sedangkan uang dan pekerjaan tidak terdapat dalar $\quad h$ ini.

d. Syirkah inan, yakni kerja sama antara dua orang atau lebih dalam permodalan untuk melakukan suatu bisnis atas dasar profit and loss sharing (membagi untung dan rugi) sesuai dengan jumlah modalnya masing-masing. Syirkah 
semacam ini disepakati oleh ulama tentang bolehnya (ijma' ulama) (Sabiq, 1981:294-298).

e. Syirkah Mudharabah (An-Nabhani, 1996:180), yakni perseroan yang disebut juga dengan qiradh.

Yakni apabila ada badan dengan harta melebur untuk melakukan suatu syirkah (perseroan). Dengan kata lain, ada seseorang memberikan hartanya kepada pihak lain yang digunakan untuk bisnis, dengan ketentuan keuntungan (laba) yang diperoleh akan dibagi oleh masing-masing pihak sesuai dengan kesepakatan. Hanya saja, ketika terjadi kerugian dalam syirkah ini, kerugiannya tidak dialamatkan kepada pihak-pihak yang melakukan syirkah, namun dikembalikan kepada ketentuan syara'.

Menurut syara', kerugian dalam syirkah mudharabah secara khusus dibebankan atas harta. Dalam arti, tidak dibebankan kepada pengelola (manager) yang hanya mempunyai keahlian saja. Apabila antara pemilik modal dengan pengelola (menejer) sama-sama sepakat bahwa keuntungan dan kerugian dibagi dua (50\%:50\%), maka keuntungan dan kerugian dibagi berdua, sedangkan kerugiannya dikembalikan kepada harta (pemilik hartashahibul mal). Sebab, syirkah tersebut statusnya sama dengan wakalah, di mana hukum orang yang menjadi wakil tidak bisa menanggung kerugian, sehingga kerugian tersebut hanya ditanggung oleh pihak yang mewakilkan saja (AnNabhani, 1996:161). (El-Ashker, 1967:75).

Syirkah mudharabah yang juga disebut commenda (el-Ashker, 1967:75).

tidak sah sampai modalnya diserahkan kepada pihak pengelola, kemudian masing-masing saling memberikan kepercayaan. Pihak pemodal tidak diperbolehkan turut bekerja dengan pengelolanya. Hanya saja, pihak pengelola tetap terikat dengan izin mengelola yang dipercayakan pihak pemodal, sehingga tidak boleh menyimpang dari izin (transaksi) tersebut.

f. Paroan perkebunan (Musaqqah), adalah termasuk syirkah di mana pemilik kebun memberikan hak pemeliharaan atas kebunnya, sedangkan hasil dibagi menurut akad (Lubis, 1995:416).

Musaqqah terbagi dua macam yaitu muzara'ah yaitu mengelola tanah orang dengan memperoleh sebagian hasilnya. Paroan sawah atau ladang, 1/2 atau 
1/3 yang bibitnya dari pemilik tanah. Sedangkan yang kedua, mukhabarah, yakni paroan sawah atau ladang $1 / 2$ atau $1 / 3$ yang bibitnya dari yang mengelola tanah. Pembagian hasil hendaknya ditentukan seperberapa bagian masing-masing, seperti $1 / 2,1 / 3$, dan seterusnya dari hasil bersih supaya tidak ada pihak yang dirugikan.

Demikianlah di antara contoh syirkah dalam Islam. Tentu saja masih ada contoh-contoh lain yang tidak diungkap dalam tulisan ini.

Selanjutnya, kapan syirkah itu dinyatakan bubar. Syirkah adalah merupakan transaksi yang menurut syara' hukumnya mubah (An-Nabhani, 1996:167). Karena itu syirkah menjadi batal karena meninggalnya salah seorang yang bertransaksi, atau salah seorang di antara mereka gila, atau dikendalikan pihak lain karena kebodohannya, atau karena salah seorang di antara mereka membubarkannya.

Apabila salah seorang pihak (dalam ikatan syirkah) menuntut pembubaran, maka pihak yang lain harus memenuhi tuntutan tersebut. Bilamana mereka terdiri dari beberapa pihak, kemudian salah seorang di antara mereka menuntut pembubaran, sedangkan yang lain tetap bersedia melanjutkan syirkahnya, maka yang lain statusnya tetap sebagai pihak yang terikat syirkah. Dan ada kemungkinan syirkah itu perlu diperbarui.

\section{Perusahaan Bisnis Negara (The State's Business Enterprise)}

Perusahaan milik negara ini (dalam sejarah Islam) muncul pada awalnya tuan tanah yang mengikuti pemimpinnya yang kalah perang, dan akhirnya tanah yang ditinggalkannya itu diambil/dikuasai oleh pemerintahan Islam sebagai kelompok yang menang dalam peperangan.

Selanjutnya tanah itu oleh negara (Islam) dipergunakan untuk kepentingan negara dalam hal perbaikan perekonomian. Tanah diolah oleh masyarakat kecil sebagai usaha pertanian. Usaha seperti ini terus berkembang sampai pada masa pemerintahan Dinasti Umayyah (El-Ashker, 1967:69). Sekarang peran besar negara ini bisa kita lihat di beberapa bagian belahan dunia Islam.

Para sarjana Muslim sepakat agar negara menguasai dan memiliki aset perekonomian sebagai wadah pemasok income perkapita. Maksudnya, sebagai 
wadah pemasok dan pelayan semua kebutuhan masyarakat, di samping untuk mengantisipasi (mengontrol) pelanggaran sektor swasta.

Di negara-negara Islam modern, seperti halnya di Kuwait, Departemen Keuangan Kuwait menguasai 49\%, sedangkan di Bank Islam Dubai, negara memasok (menguasai) 20\% dari produk perusahaan. Selebihnya, negara bertanggung jawab untuk mengatur (legulator) dan mendistribusikannya untuk kepentingan rakyat(El-A shker, 1967:70).

Dilihat dari jumlah pemilik, menurut perundangan negara yang berlaku, perusahaan dapat diklasifikasikan menjadi perusahaan perseorangan dan perusahaan perseketuan. Perusahaan perseorangan didirikan dan dimiliki oleh satu orang pengusaha. Inilah yang dimaksud dengan tijaratun fardiyah dalam hukum Islam. Perusahaan persekutuan didirikan dan dimiliki oleh beberapa orang pengusaha yang bekerja sama dalam satu persekutuan (partnership) yang di dalam Islam dikenal dengan sebutan syirkah dengan berbagai bentuknya. Sedangkan dilihat dari status pemiliknya, perusahaan diklasifikasikan menjadi perusahaan swasta (Dahlan dan Bintang, 2000:25-26).4 dan perusahaan negara (Head, 1997:7.5 Perusahaan swasta adalah sejenis perusahaan yang dikuasai dan dimiliki oleh pihak swasta (masyarakat). Adapun perusahaan negara adalah perusahaan yang dikuasai dan dimiliki oleh negara yang lazim disebut Badan Usaha Milik Negara (BUMN). Klasifikasi perusahaan yang kedua ini juga ada dalam Islam sebagaimana telah disinggung sebelum ini.

Di sisi lain dilihat dari bentuk hukumnya, perusahaan diklasifikasikan menjadi perusahaan badan hukum dan perusahaan bukan badan hukum. Dalam praktiknya, perusahaan badan hukum ada yang dimiliki oleh swasta seperti Perseroan Terbatas (PT), dan ada pula yang dikuasai oleh negara seperti Perusahaan Umum (Perum), Perusahaan Perseroan (Persero), dan Perusahaan Daerah. Perusahaan badan hukum dalam bentuk PT selalu berupa persekutuan, sedangkan perusahaan bukan badan hukum dapat berupa perusahaan

\footnotetext{
${ }^{4}$ Perusahaan swasta, modal usahanya dimiliki seluruhnya atau sebagian besar oleh pihak swasta. Usaha swasta ini dilihat dari besar kecilnya skala usaha terdiri dari usaha kecil, usaha menengah, dan usaha besar. Dalam kenyataan, usaha swasta jumlahnya paling banyak jika dibandingkan dengan usaha negara dan usaha koperasi. Oleh karena itu, perannya cukup besar di dalam perekonomian nasional.

${ }^{5}$ Perusahaan Negara yang seringkali disebut Badan Usaha Milik Negara (BUMN) adalah perusahaan yang dimiliki secara mutlak atau sebagian besar oleh Negara. Pengaturan BUMN di Indonesia terdapat dalam Undang-Undang Republik Indonesia Nomor 9 Tahun 1969 tentang penetapan Peraturan Pemerintah Pengganti Undang-Undang Nomor 1 Tahun 1969 tentang Bentuk-bentuk Usaha Negara. Pengaturan Lebih lanjut terdapat dalam Peraturan Pemerintah Republik Indonesia Nomor 12 Tahun 1998.
} 
perseorangan dan perusahaan persekutuan yang hanya dimiliki oleh swasta (Muhammad, 1999:46).

Bertolak dari uraian di atas, maka dapat diketahui ada tiga jenis bentuk hukum perusahaan: (a) Perusahaan perseorangan yaitu perusahaan swasta yang didirikan dan dimiliki oleh pengusaha perseorangan, dan bukan badan hukum. Perusahaan perseorangan dapat mempunyai bentuk hukum menurut bidang usahanya, seperti perusahaan industri (batik, perak, bata), perusahaan dagang (toko swalayan, barang elektronik, restoran/rumah makan), dan perusahaan jasa (salon kecantikan, bengkel, tailor); (b) Perusahaan persekutuan bukan badan hukum adalah perusahaan swasta yang didirikan dan dimiliki oleh beberapa orang pengusaha secara bersama. Perusahaan persekutuan bukan badan hukum dapat menjalankan usaha dalam semua bidang perekonomian, yaitu bidang industri, dagang, dan jasa. Perusahaan persekutuan dapat mempunyai bentuk hukum berupa Firma (Fa) dan Persekutuan Komanditer (CV); (c) Perusahaan badan hukum terdiri dari perusahaan swasta yang didirikan dan dimiliki oleh beberapa orang pengusaha secara kerja sama dan perusahaan negara. Perusahaan badan hukum dapat menjalankan usaha dalam semua bidang perekonomian. Perusahaan badan hukum mempunyai bentuk hukum Perseroan Terbatas (PT) dan Koperasi yang dimiliki swasta, Perusahaan Umum (Perum), dan Perusahaan Perseroan (Persero) yang dimiliki negara (Muhammad, 1999:46).

Dengan demikian, Fa dan CV, termasuk dalam kategori bukan badan hukum, sedangkan PT, Perum, dan Persero masuk dalam badan hukum. PT merupakan Badan Hukum Milik Swasta (BUMS), sedangkan Perum dan Persero merupakan Badan Usaha Milik Negara (BUMN) (Dahlan dan Bintang, 2000:26).6

Organisasi atau badan usaha tersebut ada yang sudah diatur dalam undang-undang dan ada pula yang belum diatur (Dahlan dan Bintang, 2000:2551). Bentuk perusahaan perseorangan, misalnya Perusahaan Otobis (PO) dan Perusahaan Dagang (PD) (Dahlan dan Bintang, 2000:26), ${ }^{7}$ belum ada pengaturannya dalam undang-undang, melainkan berkembang sesuai kebutuhan masyarakat pengusaha yang dalam praktiknya dibuat tertulis di muka notaris

\footnotetext{
${ }^{6}$ Yang termasuk dalam perusahaan negara (BUMN, pada umumnya meliputi Perusahaan Jawatan (Perjan), Perusahaan Umu m (Perum), dan Perusahaan Perseroan (Persero).

7 Perusahaan Dagang atau Usaha Dagang yang disingkat UD, merupakan bentuk usaha paling sederhana yakni usaha swasta yang pengusahanya satu orang. Yang dimaksud pengusaha di sini adalah pemilik perusahaan. Modal atau investasi yang dimaksudkan dapat berupa uang, benda, atau tenaga (keahlian), yang semuanya bernilai uang.
} 
(Muhammad, 1999:1). Kendati tidak semuanya di muka notaris, hanya saja harus memenuhi kewajiban antara lain untuk memperoleh Tanda Daftar Perusahaan (TDP) pada Departemen Perindustrian dan Perdagangan, Surat Izin Usaha Perdagangan (SIUP), memperoleh Surat Izin Tempat Usaha (SITU) dari pemerintah daerah setempat, dan memperoleh izin berdasarkan Undang-Undang Gangguan (Hinder Ordonnantie $=$ HO Stb 1926 Nomor 226) atau melakukan Analisis Mengenai Dampak Lingkungan (AMDAL) sebagaimana diatur dalam perundang-undangan lingkungan hidup (Dahlan dan Bintang, 2000:28).

Sedangkan untuk bentuk hukum perusahaan dan badan hukum yang sudah diatur dalam perundangan, misalnya Firma (Fa) (Swasta dan Sukotjo, 2002:55) dan Persekutuan Komanditer (CV) (Muhammad, 1999:55), diatur dalam Kitab Undang-Undang Hukum Dagang (KUHD), Perseroan Terbatas (PT) (Dahlan dan Bintang, 2000:33) diatur dalam Undang-Undang Nomor 1 Tahun 1995. Badan Usaha Koperasi (Dahlan dan Bintang, 2000:46) diatur dalam UndangUndang Nomor 25 Tahun 1992. Adapun bentuk-bentuk perusahaan negara (BUMN) yang ditentukan dalam Undang-Undang Nomor 9 Tahun 1969 diklasifikasikan menjadi tiga jenis yakni: (a) Perusahaan Jawatan (Perjan) ${ }^{8}$ diatur dalam Indinesiasche-Berdrijvenwet (Stb. No.419 Tahun 1927); (b) Perusahaan Umum (Perum) (Dahlan dan Bintang, 2000:44) 9 diatur dalam Undang-Undang Nomor 19 Tahun 1960, dan (c) Perusahaan Perseroan (Persero) (Dahlan dan Bintang, 2000:45-46)10 diatur dalam Peraturan Pemerintah Nomor 12 Tahun 1969 (Muhammad, 1999:46-47).

\footnotetext{
${ }^{8}$ Perjan adalah BUMN yang seluruh modalnya terdiri dari kekayaan negara yang tidak dipisahkan. Perjan merupakan bagian dari instansi pemerintah tertentu dan pegawainya adalah pegawai negeri sipil yang tunduk pada perundangan-undangan kepegawaian yang berlaku. Oleh karena itu, Perjan bukan merupakan badan hukum. Tujuan Perjan adalah semata-mata untuk meningkatkan kesejahteraan masyarakat yang sifatnya tidak mencari laba (non-commercial corporation).

${ }^{9}$ Perum adalah BUMN yang seluruh modalnya terdiri dari kekayaan negara yang dipisahkan. Oleh karena itu, Perum merupakan badan hukum publik. Pekerja di Perum merupakan pegawai perusahaan negara yang diatur secara khusus. Peru $m$ ini bergerak dalam bidang-bidang usaha tertentu yang penting bagi negara dan menguasai hajat hidup orang banyak. Dalam Peraturan Pemerintah Nomor 13 Tahun 1998 ditegaskan bahwa Perum adalah "badan usaha milik negara sebagaimana diatur dalam UndangUndang Nomor 9 Tahun 1969 di mana seluruh modalnya dimiliki negara berupa kekayaan negara yang dipisahkan dan tidak terbagi atas saham". Perum didirikan dengan Peraturan Pemerintah yang menetapkan antara lain besarnya kekayaan negara yang dipisahkan untuk penyertaan ke dalam modal Perum dan penunjukan Menteri Keuangan selaku wakil pemerintah. Perum memperoleh status badan hukum setelah peraturan pemerintah pendirian Peru m berlaku.

${ }^{10}$ Persero adalah BUMN yang seluruh atau sebagian besar modalnya terdiri dari kekayaan negara yang dipisahkan. Persero merupakan badan hukum swasta yang tunduk pada prinsip-prinsip aturan Perseroan Terbatas (PT) sebagaimana diatur di dalam UUPT. Pegawai Persero adalah pekerja atau buruh yang tunduk pada perundangan-undangan ketenagakerjaan atau perburuhan. Tujuan Persero sama dengan tujuan PT swasta, yaitu mencari laba (commercial corporation). Dalam Peraturan
} 
Khusus untuk bentuk hukum perusahaan perseorangan yang belum diatur dalam undang-undang tetapi keberadaannya diakui oleh pemerintah dalam praktik perusahaan, pengakuannya dapat dibuktikan dengan indentitas yang digunakan, yaitu (a) nama tertentu yang dipakai sebagai nama perusahaan, dan (b) legalitas perusahaan yaitu akta pendirian, surat izin usaha, surat izin tempat usaha (jika perlu), surat pendaftaran perusahaan (Muhammad, 1999:47).

Selain dari ketentuan undang-undang, bentuk hukum perusahaan dapat diketahui melalui anggaran dasar perusahaan yang disusun oleh pengusaha yang dituangkan dalam akta pendirian perusahaan yang dibuat di muka notaris(Muhammad, 1999:47).

\section{TUJUAN PERUSAHAAN DALAM ISLAM}

Dalam hukum ekonomi klasik berlaku semboyan: "mencari keuntungan sebesar-besarnya dengan biaya yang sekecil-kecilnya". Memahami semboyan ini konsekuensi logisnya, lahirlah apa yang dikenal dengan semboyan homo homini lopus, artinya manusia yang satu menjadi serigala manusia lainnya.

Praktiknya, dalam dunia usaha (bisnis) manusia sebagai pelaku seringkali menempuh modus menghalalkan segala macam cara. Tujuan akhir yang mendorong sikap ke-aku-an ini (ananiyah) ini hanya satu, yaitu meraih keuntungan yang sebanyak-banyaknya untuk kekayaan pribadi. Apabila tujuan itu tercapai, subjek pelakunya akan merasa puas, sekalipun nilai kepuasaan itu hanyalah sementara dan semu belaka.

Tidaklah demikian halnya dalam Islam. Seorang pengusaha menurut Islam - secara umum - harus berkiblat kepada tuntutan syara' yang bersumber pokok pada al-Qur'an dan Hadits. Bila kita gali dari kedua sumber ini paling tidak seorang pengendali perusahaan akan memperhatikan prinsip persamaan

Pemerintah Nomor 12 Tahun 1998 ditegaskan bahwa terdapat dua macam Persero yaitu Persero dan Persero terbuka. Persero adalah "badan usaha milik negara yang dibentuk berdasarkan Undang-Undang Nomor 9 Tahun 1969 yang berbentuk Perseroan Terbatas sebagaimana dimaksud dalam UndangUndang Nomor 1 Tahun 1995 yang seluruh atau paling sedikiit 51\% saham yang dikeluarkannya dimiliki oleh negara melalui pernyataan modal secara langsung. Sedangkan Persero terbuka adalah "Persero yang modalnya dan jumlah pemegang sahamnya memenuhi kreteria tertentu atau persero yang melakukan penawaran umum, sesuai dengan peraturan perundangan di bidang pasar modal". Berkaitan dengan maksud dan tujuan pendirian Persero Peraturan Pemerintah Nomor 2 Tahun 1998 merinci sebagai-berikut: (a) menyediakan barang dan atau jasa yang bermutu tinggi dan berdaya saing kuat, baik di pasar dalam negeri maupun internasional; (b) memupuk keuntungan guna meningkatkan nilai perusahaan. 
dan toleran (tasamuh), keadilan ('adalah), dan saling menolong (ta'awun) yang saling menguntungkan.

Prinsip persamaan dan penuh toleransi dimaksudkan bahwa semua manusia atau semua pihak dalam kaitan dengan perusahaan, baik majikan (manajer), buruh, produsen sampai dengan konsumen mempunyai kedudukan yang sama di muka hukum (Islam). Untuk itu mereka harus berhati-hati (ikhtiyad) dan bersikap menghargai orang lain dalam menjalankan fungsi masing-masing dengan berpegang teguh pada nilai dan norma yang berlaku. Jika tidak, tanpa kecuali, mereka akan terkena sanksi.

Keadilan dimaksudkan bahwa seorang produsen harus mempekerjakan pekerja (bawahan) dengan memberi upah atau penghargaan lain (kompensasi) secara adil dan proporsional. Demikian juga terhadap konsumen, antara lain bagaimana agar kualitas produksi (barang) sesuai dengan standar harga sehingga pemakainya merasa tidak dirugikan secara materi dan memperoleh kepuasaan secara batini.

Sedangkan prinsip saling tolong perlu adanya kesadaran dari semua pihak, bagaimana pun dalam bisnis pada hakikatnya pihak yang satu (produsen) membantu pihak lain (konsumen). Atau sebaliknya konsumen membantu produsen karena bersedia menggunakan produknya. Dalam hal ini produsen akan memperoleh keuntungan secara materi, sebagaimana konsumen memperoleh kepuasan atas barang yang dikonsumsi. Oleh karena itu, bertolak dari prinsip-prinsip ini seorang produsen (pengusaha) bagaimanapun harus bertanggung jawab secara individual atas barang yang dihasilkan, termasuk risiko yang mungkin timbul (Pratley, 1997:105).

Menurut falsafah al-Qur'an, semua aktivitas yag dapat dilakukan oleh manusia patut dikerjakan untuk mendapatkan falah, yaitu kerelaan Allah swt untuk menggapai kesempurnaan dunia dan akhirat (Siddiqi, 1991:3). Jika falah ini dapat dicapai, manusia akan mendapatkan kebahagiaan dunia dan akhirat, suatu keadaan di mana kedua aspek tersebut tidak menimbulkan konflik kepentingan, termasuk kepentingan bisnis.

Kekayaan materi merupakan bagian penting dalam falah. Bahaya kelaparan, sulitnya mendapatkan kebutuhan hidup dan faktor-faktor lain yang mengganggu pikiran dan tubuh (fisik) tentu tidak akan menciptakan suasana yang menyenangkan untuk mencapai tujuan hidup di dunia. Islam tidak mencela 
akan kebutuhan materi dalam aktivitas kehidupan manusia (Siddiqi,1991:11). Di sinilah letak signifikansinya, justru mengapa manusia harus bekerja, antara lain dengan berbisnis.

Muhammad Nejatullah Siddiqi, dalam bukunya, The Economic Enterprise in Islam, memformulasikan tujuan perusahaan sebagai tujuan aktivitas ekonomi. Di mana tujuan yang sempurna menurut Islam dapat diringkas sebagai-berikut: (1) memenuhi kebutuhan hidup seseorang seara sederhana; (2) memenuhi kebutuhan keluarga; (3) memenuhi kebutuhan jangka panjang; (4) menyediakan kebutuhan keluarga yang ditinggalkan; dan (5) memberikan bantuan sosial dan sumbangan menurut jalan Allah swt (Siddiqi,1991:15).

Nampaknya tujuan aktivitas ekonomi yang dikemukakan Siddiqi di atas mengintensitaskan kepada aspek kerohanian (spiritualitas) dan menjadikan materi sebagai instrumen kehidupan, bukan tujuan akhir.

Tujuan aktivitas ekonomi pertama-tama diarahkan untuk memenuhi kebutuhan diri tanpa berlebihan sebelum untuk memenuhi tuntutan (kewajiban) atas keluarga, baik jangka pendek maupun jangka panjang. Baru setelah itu mengekspansi untuk kepentingan eksternal yakni kepentingan sosial dan perjuangan menurut jalan Allah swt. Dalam hal ini dimaksudkan agar setiap pengusaha selaku pelaku bisnis harus menyadari bahwa keuntungan perusahaan yang diperoleh pada hakikatnya merupakan amanah dan milik Allah swt. Sebagai amanah, diharapkan agar harta $(m a \bar{l})$ itu mempunyai fungsi sosial sehingga wajib disampaikan kepada sasaran yang berhak (mustahiq) sesuai dengan petunjuk syariat. Dengan demikian, kekayaan itu tidak terakumulasi hanya untuk kepentingan domestik (internal) pemilik harta semata. Tetapi perlu ada keseimbangan (balance-tawazun) dengan kepentingan sosial (eksternal) sehingga kesenjangan tidak akan terjadi.

Modus penyaluran atau pemerataan kekayaan itu yang bersifat produktif antara lain dengan mempekerjakan para karyawan, investasi sesuai petunjuk syariah, atau melakuan usaha sesuai dengan lembaga-lembaga perekonomian sebagaimana diuraikan di atas. Sedangkan yang bersifat sosial atau konsumtif, antara lain bisa berbentuk zakat, hibah, wasiat, infak, dan sedekah. 


\section{KESIMPULAN}

Islam menekankan bahwa bekerja (berusaha) tidak hanya merupakan kewajiban sosial (insaniyah), namun juga kewajiban syar'i (uluhiyah). Karena itu setiap orang (Muslim) yang berkiprah sebagai pelaku bisnis (pengusaha) berarti ia harus melaksanakan dua kewajiban sekaligus. Dalam bekerja guna memenuhi kebutuhan hidupnya, Islam memberi keleluasaan kepada umatnya untuk memilih profesi sesuai pilihan, minat, dan kemampuan masing-masing. Antara lain adalah melalui dunia bisnis dengan membuka beragam jenis usaha. Dalam hal ini, Islam memberi ruang kepada umatnya dengan prinsip "boleh melakukan bisnis apa saja, kecuali apabila ada ketentuan hukum yang melarangnya."

Dengan kata lain, dalam membuka usaha, sebagaimana dalam peraturan perundangan modern, seorang pelaku bisnis Muslim diberi otoritas dalam Islam untuk memilih berbagai macam usaha sesuai dengan cara dan bentuk sesuai koridor hukum yang berlaku. Dalam memasuki dunia usaha, pelaku bisnis bisa melakukan secara mandiri yang dikenal dengan bisnis perseorangan. Atau, melakukannya dengan cara berjamaah yang dikenal dengan syirkah (persekutuanpatnership). Bahkan Islam sebagaimana pula dalam perundangan modern membenarkan bisnis yang dilakukan oleh negara (state) agar negara menjadi kuat selaku institusi yang bertanggung jawab atas kesejahteraan warga negara nya.

Di sisi lain Islam mengingatkan bahwa dalam membangun perusahaan sebagian dari keuntungan yang diperoleh harus dimanfaatkan untuk memenuhi kepentingan diri, keluarga dan masyarakat untuk mencapai ke sejahteraan (falah) dalam ridla Allah swt. Untuk mencapai falah ini Islam mensyaratkan agar dalam melakukan bisnis para pelaku bisnis tidak memberikan mudlarat (bahaya) kepada orang lain. Sebaliknya, mereka juga tidak boleh ditimpa mudlarat dari orang lain. Dengan demikian dalam melakukan bisnis, hendaknya antar pihak yang terlibat perlu saling melindungi di atas prinsip persamaan dan toleransi (tasamuh), mengedepankan keadilan ('adalah), dan saling tolong-menolong (ta'awun) antara yang satu dengan yang lain.

Untuk dapat menggapai falah dalam aktivitas bisnis apa pun, Islam mengajarkan pelaku agar tidak saja mengejar materi yang melimpah yang bersifat profan, nisbi, dan sesaat dalam kehidupan duniawi. Namun yang perlu dikejar adalah kebahagiaan yang hakiki yang transenden sebagai bekal hidup bagi perlakunya kelak di akhirat yang abadi. Justru karena itu dalam melakukan 
bisnis, para pelakunya, apakah mereka sebagai produsen maupun penjual (pemasar), hendaknya mengedepankan dan mencermati dengan saksama, apakah produk yang akan dikonsumsi oleh masyarakat itu layak dan aman secara ilmu kesehatan (medis) dan halal secara hukum (yuridis). Mengabaikan aspek ini mustahil para pelaku bisnis akan mendapat falah, oleh karena aktivitas bisnis (usahanya) yang mereka lakukan telah merugikan orang lain.

Di sinilah makna falah yang diajarkan oleh Islam yang di dalamnya ter sirat makna kebahagiaan, tidak saja di dunia, bahkan juga di akhirat. Ajaran seperti ini sudah barang tentu tidak dikenal di dalam doktrin perundangan produk manusia mana pun di dunia. Dan di sini pula jika secara jujur dikatakan sisi keunggulan hukum Islam yang bersumber dari ajaran Allah swt Yang Maha Adil yang jauh dari kepentingan sebagaimana hukum produk pemikiran manusia yang serba terbatas dan tidak jarang penuh bias. 


\section{DAFTAR PUSTAKA}

Al-Khayyath, Abdul Aziz. 1995. Etika Bekerja dalam Islam, ter. Moh. Nurhakim. Jakarta: Gema Insani Press.

Al-Qur'an dan Terjemahnya

Antonio, Muhammad Syafii. 1997. “Asuransi dalam Perspektif Islam”, dalam Mustafa Kamal (ed), Wawasan Islam dan Ekonomi: Sebuah Bunga Rampai. Jakarta: LPFE UI.

An-Nabhani, Taqiyuddin. 1996. Membangun Sistem Ekonomi Alternatif: Perspektif Islam, ter. Moh. Maghfur Wachid. Surabaya: Penerbit Risalah Gusti.

Dahlan dan Sanusi Bintang. 2000. Pokok-Pokok Hukum Ekonomi dan Bisnis. Bandung: PT Citra Aditya Bakti.

El-Ashker, Ahmed Abdel Fattah. 1967. The Islamic Business Enterprise. London: Croom Helm.

Head, John W. 1997. Pengantar Umum Hukum Ekonomi. Jakarta: Proyek ELIPS.

Isa, Abdurrahman. tt. Al-Mu'amalāt al-Haditsah wa Ahkamuhā. Mesir: Mathba'ah Mukhaimir.

Kitab Undang-Undang Hukum Perdata (KUHPdt)

Kitab Undang-Undang Hukum Dagang (KUHD)

Lubis, H. Ibrahim. 1995. Ekonomi Islam: Suatu pengantar II. Jakarta: Kalam Mulia.

Mannan, M. Abdul. 1995. Teori dan Praktek Ekonomi Islam, ter. M. Nastangin. Yogyakarta: Penerbit PT. Dana Bhakti Wakaf.

Muhammad, Abdulkadir. 1999. Hukum Perusahaan di Indonesia, Bandung: PT. Citra Aditya Bakti.

Pratley, Peter. 1997. Etika Bisnis, ter. Gunawan Prasetio. Yogyakarta: Penerbit Andi.

Projodikoro, Wiryono. 1996. Hukum Asuransi di Indonesia. Jakarta: PT. Internas.

Sabiq, Sayid. 1981. Fiqh al-Sunnah Vol. III. Libanon: Darul Fikar.

Siddiqi, Muhammad Nejatullah. 1991. Kegiatan Ekonomi Islam, alih bahasa: Anas Sidik. Jakarta: Bumi Aksara.

Swasta, Basu dan Ibn Sukotjo. 2002. Pengantar Bisnis Modern. Yogyakarta: Liberty. 
Tim Penulis Dewan Syariah Nasional Majelis Ulama Indonesia. 2003. Himpunan Fatwa Dewan Syariah Nasional. Jakarta: Dewan Syariah Nasional Majelis Ulama Indonesia dan Bank Indonesia.

Undang-Undang Republik Indonesia Nomor 9 Tahun 1969 tentang Penetapan Peraturan Pemerintah Pengganti Undang-Undang Nomor 1 Tahun 1969 tentang Bentuk-bentuk Usaha Negara

Zuhdi, H. Masjfuk. 1993. Studi Islam Jilid III:Muamalah. Jakarta: PT. Raja Grafindo Persada. 